\title{
Investigation of Groundwater Potential using Electrical Resistivity Method and Hydraulic Parameters in Lam Apeng, Aceh Besar, Indonesia.
}

\author{
Dian Darisma $^{1 *}$, Ferdy Fernanda ${ }^{1}$, Muhammad Syukri $^{1,2 *}$ \\ ${ }^{I}$ Department of Geophysical Engineering, Faculty of Engineering, Universitas Syiah Kuala, Aceh, Indonesia. \\ ${ }^{2}$ Department of Physics, Faculty of Mathematics and Natural Sciences, Universitas Syiah Kuala, Aceh, Indonesia.
}

\author{
* Corresponding author: diandarisma@ unsyiah.ac.id, m.syukri@unsyiah.ac.id. \\ Tel.:+62-852-6097-1289 \\ Received: Aug 24, 2020; Accepted: Sept 22, 2020 \\ DOI : 10.25299/jgeet.2020.5.4.5501
}

\begin{abstract}
Lam Apeng is a village with a majority of people living as farmers, which causes the need of water for agriculture is increasing. The water demand in this area continues to increase as the population increases, for various purposes. The objective of this study is to determine the distribution of the groundwater layer using the electrical resistivity method and to determine groundwater potential using hydraulic parameters. This research is conducted using 2 measurement line with a length of each line is 112 meters and distances of each electrode is 2 meters. The data invert using Res2Dinv software to obtain 2D subsurface lithology subsurface. At line 1, the aquifer (sand) layer is located in the second layer with a rock resistivity value of $12 \Omega \mathrm{m}-18.6 \Omega \mathrm{m}$ at a depth of $8 \mathrm{~m}-18 \mathrm{~m}$. At line 2, the aquifer (sand) layer is also located in the second layer with a resistivity value of $4.6 \Omega \mathrm{m}-18 \Omega \mathrm{m}$ at a depth of $5 \mathrm{~m}-12 \mathrm{~m}$. Based on the interpretation of the two measurement lines, it can be concluded that the type of aquifer in the research site is a semi unconfined aquifer. In this study, hydraulic parameters (hydraulic conductivity, longitudinal conductance, transverse resistance, and transmissivity) was calculated based on the resistivity value and the thickness of the aquifer layer. The average resistivity of the aquifer layer used is $15.3 \Omega \mathrm{m}$ and $11.3 \Omega \mathrm{m}$, respectively for line 1 and line 2 , indicating that the aquifer was moderately corrosive. Longitudinal conductance values are $0.65 \Omega^{-1}$ and $0.62 \Omega^{-1}$ which indicated moderate protective capacity. The transmissivity values are 6.78 $\mathrm{m}^{2} /$ dayand $4.77 \mathrm{~m}^{2} /$ day, which indicates that the designation in this area is low and the groundwater potential is local or only for personal consumption.
\end{abstract}

Keywords: Groundwater, Electrical Resistivity, Hydraulic Parameter, Lam Apeng.

\section{Introduction}

Water is an essential element for all life forms on Earth Water covers nearly $71 \%$ of the Earth's surface which is in the form of liquid, ice, and gas. Based on the place of origin, water is divided into 2 types, namely water that is on the surface and water that is below the surface. Groundwater is water that is found in the soil or rock layers below the surface. According to Fetter (2001), soil and rock pores become saturated with water at a certain depth. The uppermost saturated zone is called the watertable. Water stored in the saturated zone is called groundwater, which then moves as groundwater flow through rocks, or seepage (aquifer) and collects in ponds, lakes, rivers, and sea. Davis and De Wiest (1966) define water entering freely into the well, either unconfined or confined.

The potential of groundwater depends on the porosity and ability of rocks to discharge water. The use of groundwater it self as a means of life is gradually increasing for industrial and household needs (Chandra et al., 2010; Suryadi et al., 2018). The existence of continuous extraction of groundwater can exceed the capacity of an aquifer. So that new aquifer sources are needed.

\section{Geological Setting}

Lam Apeng Village is located in Seulimum Subdistrict, Aceh Besar. The topography in the northern area of the study tends to be flat and continues to rise to the south towards
Seulawah Agam Volcano. The majority of the land is used as agricultural land and part of the land is still forest area.

Based on the regional geological map of Aceh Besar, Lam Apeng Village is in the branching zone of the Sumatra Fault Segment so that there are many local faults. The geological structure of the Lam Apeng area is dominated by rocks originating from boulders of volcanic eruptions, namely the Lam Teuba volcanic rock formations. This formation consists of volcanic rocks from andesite to dacite, pumice breccia, tuff, sandstone, and young volcanic deposits, including tuff, lava, breccia, and lava andesite to basalt. The tuff rocks are light brown to light gray, slightly hard, silt grain size to fine sand, which can be seen in fig 1 .

Dacite rock is dark gray, hard, vesicular structure, large fine crystal grains: aphanitic, hypocrystalline, in equigranular, glass mineral, muscovite, and quartz. Volcanic breccia rock consists of fragments of volcanic material, namely dacite andesite rock, glass mixed in one volcanic deposit which is included in volcanic rock. (Barber et al., 2005).

Lam Apeng is a village that has extensive agricultural and plantation land. As a result of these plantations and agricultural activities, water reserves are needed for these lands, where almost all of these communities work as farmers. In this area, the farmers use the river flow to meet the needs of their plantations, wherein the dry season the water discharge in the river has decreased due to the absence of rain in the upstream 
river and also difficult access to get the water. Therefore, research is needed to identify the location of groundwater aquifers that can meet these needs. There are several ways to research and find groundwater reserves using geophysical methods and one of the methods that can be used is the electrical resistivity method (Alfadli and Natasia, 2017; Syukri and Saad, 2017).

The electrical resistivity method is a very suitable method for groundwater exploration because of hydrogeological properties such as porosity and permeability, which are directly related to the resistivity value. This method can measure the resistivity of the subsurface rocks which can identify rock layers, structures, and also the groundwater layer (Mohamaden et al., 2016; Muchingami et al., 2012).

The configuration used in this study is WennerSchlumberger configuration. This configuration is a combination of the Wenner and Schlumberger configurations to identify changes vertically and horizontally. There are several studies conducted to determine groundwater sources using geoelectric methods (Bayewu et al., 2018; Metwaly et al., 2010; Mohamaden and Ehab, 2017). Based on some of these studies, it proves that the geoelectric method is quite good and very effective for finding groundwater.

The resistivity and aquifer thickness values from the inversion of electrical resistivity data were used to determine aquifer parameters (soil corrosivity, protective capacity, and designation).Usually, the conventional way to estimate these parameters is through a pumping test and grain size analysis(Fetter, 2001). But the test takes longer time and is not economical (Perdomo et al., 2018; Soupios et al., 2007). Therefore, a geophysical approach (electrical resistivity method) can be used to determine hydraulic parameters (Abdulrazzaq et al., 2020; Hasan et al., 2020).

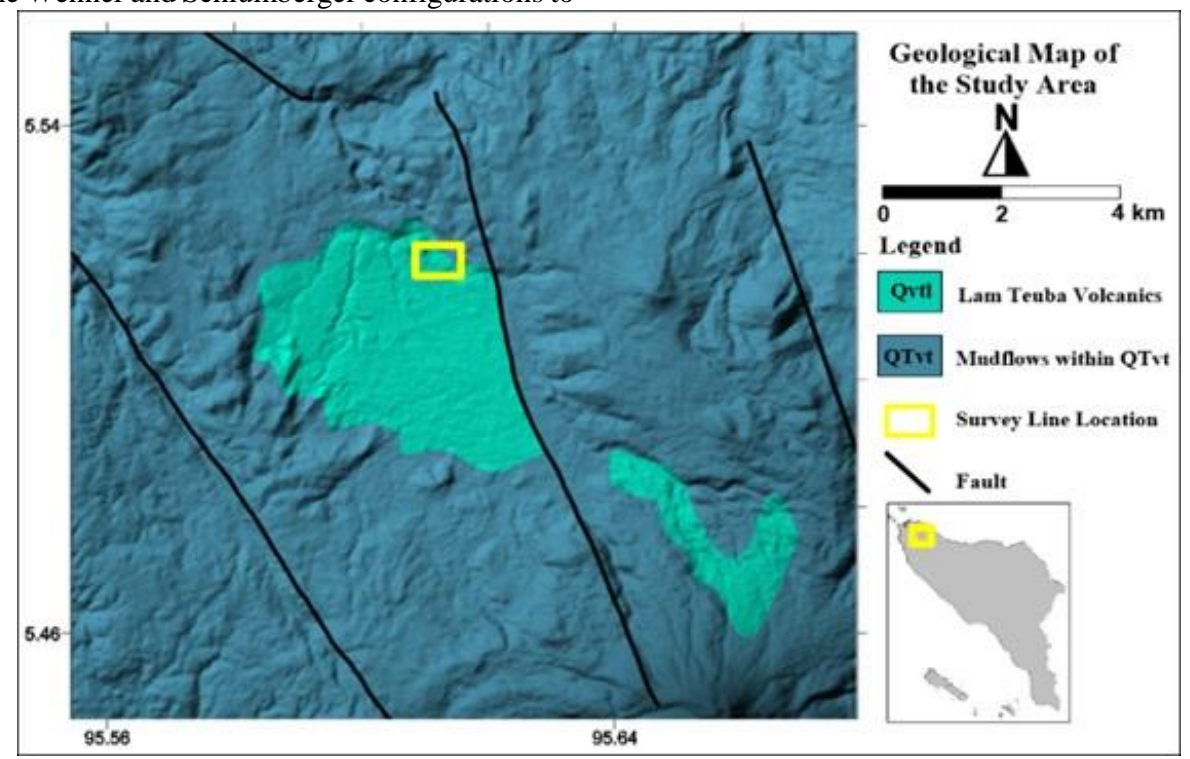

Fig. 1. Geological map of Aceh Besar (modified from Bennet et al., 1981)

\section{Methodology}

\subsection{Electrical Resistivity Method}

The electrical resistivity method is a geophysical method that utilizes electric currents to determine subsurface conditions. The results of electrical resistivity measurements cannot be used with certainty considering the many factors that influence conductivity and resistivity. Even so, the method can provide information about rock layers that contain water (aquifers). The resistivity value of rock layers containing water will be lower.

The resistivity value obtained at the beginning of the measurement is not the actual resistivity value, but the resistivity value which is usually called apparent resistivity ( $\rho$ a), which is shown by the following equation:

$$
\rho_{a}=K \frac{\Delta V}{I}
$$

where $\mathrm{K}$ is the geometric factor, $\Delta \mathrm{V}$ and $\mathrm{I}$ are the potential difference and the injected current, respectively.

The measurement of the resistivity value is obtained by placing the electrodes, which is known as the electrode configuration. The different configurations used can cause different geometric factors. The geometry factor is a correction value for the potential electrode and the current electrode. Some of the configurations that are often used for geo-electrical surveys include Wenner, Pole-Pole, and Pole-Dipole. In this study, the configuration used is the Wenner-Schlumberger configuration (Fig. 2)

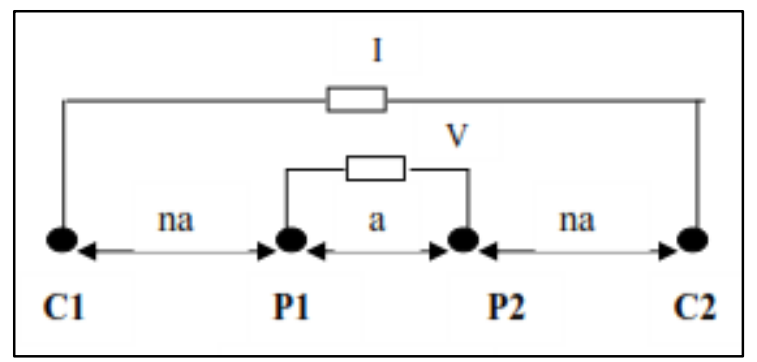

Fig. 2. Electrode configuration of Wenner-Schlumberger (Telford et al., 1990).

The Wenner-Schlumberger configuration is a combination of the Wenner and Schlumberger configurations (Dahlin, 2001). In this configuration, the distance between the electrodes $\mathrm{P} 1$ and $\mathrm{P} 2$ is a while the distance between $\mathrm{C} 1$ and P1 and P2 and $\mathrm{C} 2$ is na. The distance between the electrodes remains constant, covers well horizontally and deep penetration vertically. The result of the combination of Wenner and Schlumberger results in the value of $\mathrm{k}$ also changing according to the following equation:

$$
k=\pi n(n+1) a
$$


Data measurement in the field using the SuperSting R8/IP tool with the Wenner-Schlumberger configuration. The measurement path is in the form of two parallel straight lines.
The length of line 1 is $112 \mathrm{~m}$ with $2 \mathrm{~m}$ spacing and line 2 is 112 m with $2 \mathrm{~m}$ spacing (Fig. 3).

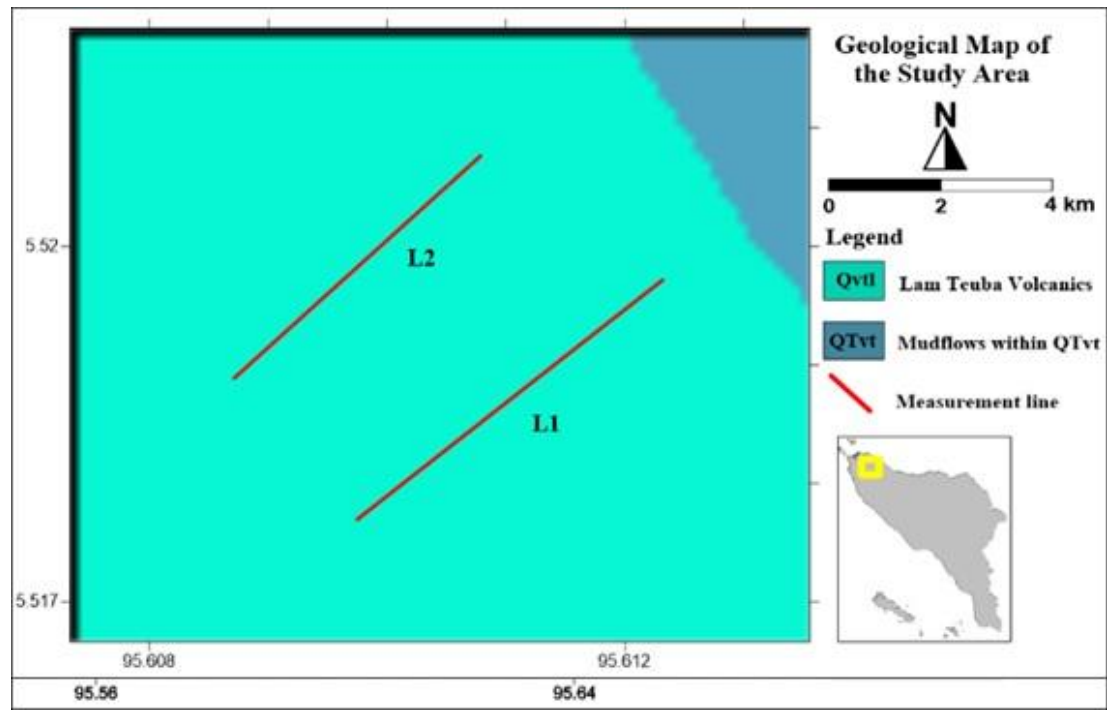

Fig. 3 Design of measurement line in Lam Apeng

The resistivity data obtained in the field will be processed using the RES2DINV software to obtain a resistivity crosssection. The program is based on the smoothness constrained least square approach (deGroot Hedlin and Constable, 1990; Sasaki, 1992; Darisma and Marwan, 2019) which generates subsurface models into rectangular blocks which then determines the optimum inversion parameter. Then the apparent resistivity value is calculated from the block model based on the finite difference or finite element method which is compared with the measurement data. This iteration processcontinues until the calculated apparent resistivity value matches the measurement value (Loke and Barker, 1996).

\subsection{Hydraulic Parameters}

The electrical resistivity method is a powerful method for groundwater exploration and water flow modeling. The result of the electrical resistivity inversion is the thickness of the aquifer $h$ and the resistivity $\rho$ which is used to calculate the hydraulic parameters. These parameters are the longitudinal conductance $S$, transverse resistance $R$, hydraulic conductivity $K$, and transmissivity $T$ (Maillet, 1947). The relationship of these parameters with thickness $h$ and resistivity is shown by the following equation,

$$
\begin{aligned}
& S=\frac{h}{\rho} \\
& R=h \rho \\
& K=8 x 10^{-6} e^{-0.0013 \rho} \\
& T=K h
\end{aligned}
$$

The hydraulic conductivity $K$ and resistivity are an indirect relationship as seen in Eq. 5. However, this relationship will be linear at low resistivity (Fetter, 2001).

The hydraulic parameters are then used to determine the soil corrosion, protective capacity, designation, and groundwater potential. Soil corrosivity is caused by iron content which can be predicted based on the resistivity value of the aquifer (Table 1) (Baeckmann et al., 1997). The protective capacity rating is inferred based on the longitudinal conductance value (Table 2). The rating is used to predict how safe a layer if a layer collapse when the water pump out from the aquifer (Henriet, 1976). Low transverse resistance shows that the rock has weathered, while high traverse resistance indicates that the rock is fresh and massive bedrock.The designation is used to predict the ability of a layer to drain fluid while the groundwater supply potential is to estimate the potential groundwater that can be extracted (Krásný, 1993). Designation and groundwater supply potential are predicted based on the transmissivity value (table 3 )

Table 1. Classification of soil corrosivity.

\begin{tabular}{ll}
\hline Soil Resistivity $(\Omega \mathrm{m})$ & Soil Corrosivity \\
\hline$<10$ & Very strongly \\
& corrosive \\
$10-60$ & Moderately corrosive \\
$60-180$ & Slightly corrosive \\
$\geq 180$ & Practically \\
& noncorrosive \\
\hline
\end{tabular}

\section{Results and Discussion}

\subsection{Two-dimensional Resistivity Model}

The results of data processing of the WennerSchlumbergerconfigurationresistivity method can be seen in Fig. 4 and 5. The results of the 2D model inversion show that at line 1 (Fig. 4) there are 3 layers. The RMS value obtained was $12.3 \%$. The top layer is interpreted as an alluvial rock layer with resistivity values ranging from $70 \Omega \mathrm{m}-109 \Omega \mathrm{m}$ at a depth of $0.5 \mathrm{~m}-8 \mathrm{~m}$. The lower layer is interpreted as a tuff rock layer which has a resistivity value of $25 \Omega \mathrm{m}-60 \Omega \mathrm{m}$ with a depth greater than $18 \mathrm{~m}$

Table 2. Classification of protective capacity.

\begin{tabular}{ll}
\hline $\begin{array}{l}\text { Longitudinal conductance } \\
\text { (mho) }\end{array}$ & $\begin{array}{l}\text { Protective capacity } \\
\text { rating }\end{array}$ \\
\hline$>10$ & Excellent \\
$5-10$ & Very good \\
$0.7-4.9$ & Good \\
$0.2-0.69$ & Moderate \\
$0.1-0.19$ & Weak \\
$<0.1$ & Poor \\
\hline
\end{tabular}


Table 3. Classification of groundwater supply potential.

\begin{tabular}{lll}
\hline Transmisivity (m/day) & Designation & \multicolumn{1}{c}{ Groundwater Supply Potential } \\
\hline 1000 & Very high & Withdrawal of great regional importance \\
$100-1000$ & High & Withdrawal of lesser regional importance \\
$10-100$ & Intermediate & Withdrawal of local water supply (small community, plant etc) \\
$1-10$ & Low & Smaller withdrawal for local water supply (private consumption) \\
$0.1-1$ & Very low & Withdrawal for local water supply (private consumption) \\
$<0.1$ & Impermeable & Sources for local water supply are difficult \\
\hline
\end{tabular}

From the model (Fig. 4), it shows that the aquifer layer is in the middle layer at a depth of $8 \mathrm{~m}-18 \mathrm{~m}$ with the carrier layer interpreted as sand with a resistivity value of $12 \Omega \mathrm{m}-18.6 \Omega \mathrm{m}$. Because of its ability to store and drain large amounts of water, this layer is conductive. The aquifer layer at line 1 is predicted to be $10 \mathrm{~m}$ thick. The interpretation of rock lithology at line 1 can be seen in Table 4.The interpretation of rock lithology at line 2 can be seen in Table 5 .

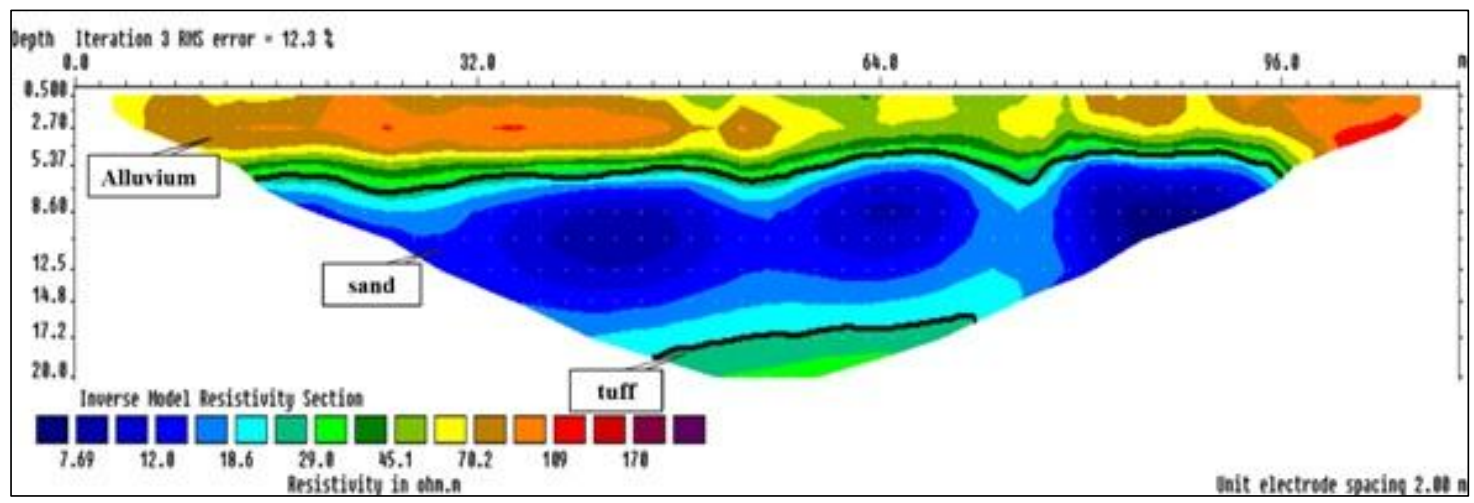

Fig. 4. Resistivity model of line 1.

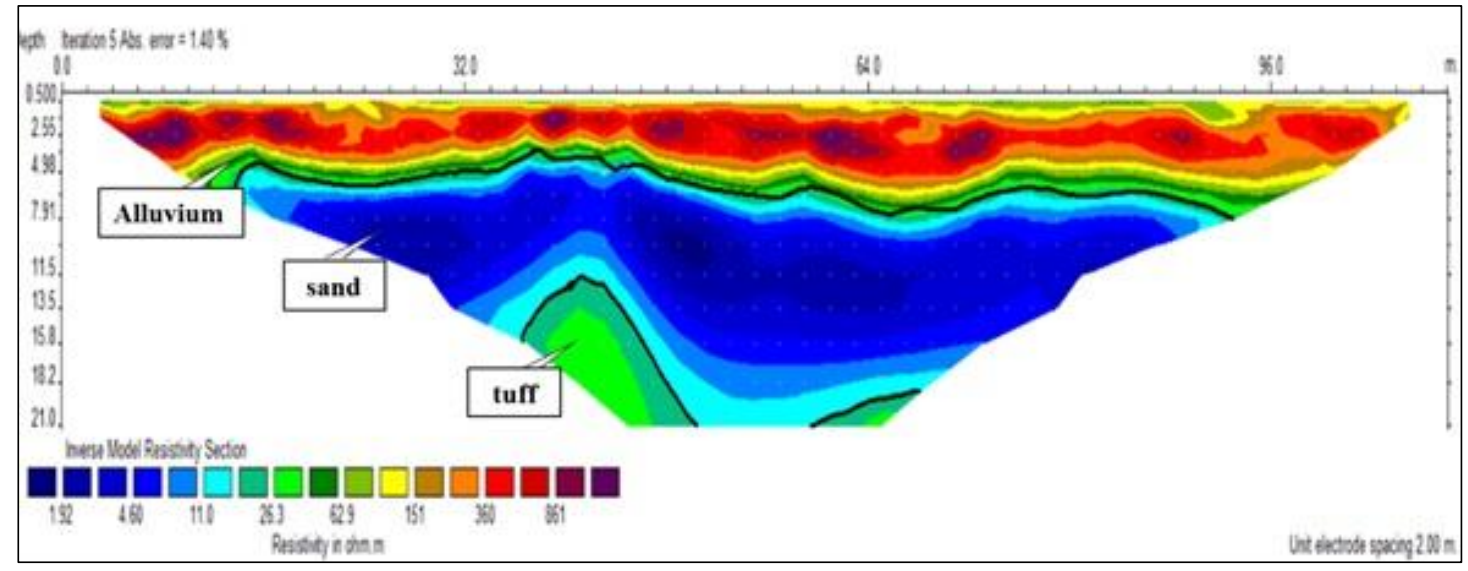

Fig. 5.Resistivity model of line 2.

The results of the inversion at line 2 can be seen in Fig. 5 which shows that 3 rock layers are similar to the model at line 1. This confirms that the inversion model at line 1 and line 2 is connected. The RMS value obtained is $1.4 \%$. The top layer consists of alluvium rocks with resistivity values ranging from $62.9 \Omega \mathrm{m}-861 \Omega \mathrm{m}$ and has a depth of $0.5 \mathrm{~m}-5 \mathrm{~m}$. The lower layer consists of tuff rock where this rock is also found at line 1 which has a resistivity value of $26.3 \Omega \mathrm{m}-100 \Omega \mathrm{m}$ with a depth of a greater than $12 \mathrm{~m}$.

Table 4. Interpretation of lithology line 1.

\begin{tabular}{|c|c|c|c|c|}
\hline Layer & $\begin{array}{l}\text { Depth } \\
\text { (m) }\end{array}$ & $\begin{array}{c}\text { Thickness } \\
\text { (m) }\end{array}$ & $\begin{array}{c}\text { Resistivity } \\
(\Omega \mathrm{m})\end{array}$ & Interpretation \\
\hline 1 & $0.5-8$ & 5 & $70-109$ & $\begin{array}{c}\text { Sand, } \\
\text { clay,gravel }\end{array}$ \\
\hline 2 & $8-18$ & 10 & $12-18.6$ & Sand (aquifer) \\
\hline 3 & $>18$ & & $25-60$ & Tuff \\
\hline
\end{tabular}

Based on the inversion model at line 2, the aquifer layer is in the middle layer at a depth of $5 \mathrm{~m}-12 \mathrm{~m}$. The carrying layer is sand with a resistivity value of $4.6 \Omega \mathrm{m}-18 \Omega \mathrm{m}$. the aquifer layer at line 2 is $7 \mathrm{~m}$ thick From the two inversion models at line 1 and line 2, it can be concluded that the aquifer is semi unconfined. This groundwater is in the layer above the watersaturated layer or tuff and under the alluvial layer that water can pass through and can also hold water.

Table 5. Interpretation of lithology line 2.

\begin{tabular}{|c|c|c|c|c|}
\hline Layer & $\begin{array}{c}\text { Depth } \\
(\mathrm{m})\end{array}$ & $\begin{array}{c}\text { Thickness } \\
\text { (m) }\end{array}$ & $\begin{array}{c}\text { Resistivity } \\
(\Omega \mathrm{m})\end{array}$ & Interpretation \\
\hline 1 & $0.5-5$ & 4.5 & $62.9-861$ & $\begin{array}{l}\text { Sand, clay, } \\
\text { gravel }\end{array}$ \\
\hline 2 & $5-12$ & 7 & $4.6-18$ & Sand (aquifer) \\
\hline 3 & $>12$ & & $26.3-100$ & Tuff \\
\hline
\end{tabular}

\subsection{Estimation of Aquifer Potential}

Based on the results of the inversion of electrical resistivity data in Lam Apeng area, the thickness of the aquifer at line 1 and line 2 is $10 \mathrm{~m}$ and $7 \mathrm{~m}$, respectively. The resistivity value 
used is the average resistivity for each line. Line 1 has a resistivity of $15.3 \Omega \mathrm{m}$ and line 2 has a resistivity of $11.3 \Omega \mathrm{m}$. The resistivity value at each line was then used to determine the level of corrosivity in the Lam Apeng area based on Table 1. The level of corrosivity in this area is classified as moderate.

Furthermore, longitudinal conductance and transverse resistance values are calculated based on Eqn. 3 and Eqn. 4. The longitudinal conductance value on each line is $0.65 \Omega^{-1}$ and 0.62 $\Omega^{-1}$, which indicates that the safety of this layer if a layer collapse is classified as moderate (Table 3).For the transverse resistance value, it generally correlates with the transmissivity value. After ward, hydraulic conductivity and transmissivity are calculated using Eqn. 5 and Eqn. 6.

Hydraulic conductivity at line 1 and line 2 is $0.678 \mathrm{~m} /$ day and $0.681 \mathrm{~m} /$ day, respectively. Meanwhile, the transmissivity is $6.78 \mathrm{~m}^{2} /$ day and $\mathrm{m}^{2} /$ day for layer 1 and layer 2 , respectively (Table 6).This shows that the fluid flow in this aquifer is very low. Aquifer properties based on hydraulic parameters are shown in (Table 7).

Table 6. Hydraulic parameter of the aquifer in Lam Apeng.

\begin{tabular}{ccccccc}
\hline Line & $\begin{array}{c}h \\
(\mathrm{~m})\end{array}$ & $\begin{array}{c}\rho \\
(\Omega \mathrm{m})\end{array}$ & $\begin{array}{c}S \\
\left(\Omega^{-}\right. \\
1\end{array}$ & $\begin{array}{c}R \\
\left(\mathrm{\Omega m}^{2}\right)\end{array}$ & $\begin{array}{c}K \\
(\mathrm{~m} / \mathrm{day})\end{array}$ & $\begin{array}{c}T \\
\left(\mathrm{~m}^{2} / \mathrm{day}\right)\end{array}$ \\
\hline 1 & 10 & 15.3 & 0.65 & 153 & 0.678 & 6.78 \\
2 & 7 & 11.3 & 0.62 & 79 & 0.681 & 4.77 \\
\hline
\end{tabular}

Table 7.Aquifer properties based on hydraulic parameters.

\begin{tabular}{|c|c|c|c|c|}
\hline Line & $\begin{array}{c}\text { Soil } \\
\text { Corrosivity }\end{array}$ & Designation & $\begin{array}{c}\text { Protective } \\
\text { Capacity }\end{array}$ & $\begin{array}{c}\text { Groundwater } \\
\text { Supply } \\
\text { Potential }\end{array}$ \\
\hline 1 & $\begin{array}{l}\text { Moderately } \\
\text { corrosive }\end{array}$ & Low & Moderate & $\begin{array}{c}\text { Smaller } \\
\text { withdrawal for } \\
\text { local water } \\
\text { supply (private } \\
\text { consumption) }\end{array}$ \\
\hline 2 & $\begin{array}{c}\text { Moderately } \\
\text { corrosive }\end{array}$ & Low & Moderate & $\begin{array}{c}\text { Smaller } \\
\text { withdrawal for } \\
\text { local water } \\
\text { supply (private } \\
\text { consumption) }\end{array}$ \\
\hline
\end{tabular}

\section{Conclusions}

The electrical resistivity method can map the presence of water layers (aquifers) well. Based on the results of the study, it can be interpreted that at line 1 and 2 has 3 layers. At line 1, the aquifer has a resistivity value of $12 \Omega \mathrm{m}-18.6 \Omega \mathrm{m}$ with a depth of $8 \mathrm{~m}-18 \mathrm{~m}$, with a sand carrier layer. At line 2 , the aquifer has a resistivity value of $4.6 \Omega \mathrm{m}-18 \Omega \mathrm{m}$ with a depth of $5 \mathrm{~m}-12 \mathrm{~m}$, with a sand carrier layer. From the inversion model, it shows that the distribution of aquifer is evenly distributed in the middle layer which has a depth of up to $20 \mathrm{~m}$. The aquifer type is a semi unconfined aquifer.

Based on the calculated hydraulic parameters, the longitudinal conductance values in this area are $0.65 \Omega^{-1}$ and $0.62 \Omega^{-1}$, respectively for line 1 and line 2 , which indicates that the ability of a layer to survive if the aquifer layer collapse is in the moderate category. The soil corrosivity level of the aquifer layer in this area is moderate with an average resistivity value of $15.3 \Omega \mathrm{m}$ and $11.3 \Omega \mathrm{m}$. The transmissivity value in this area is $6.78 \mathrm{~m}^{2} /$ day for line 1 and $4.77 \mathrm{~m}^{2} /$ day for line 2 which indicates that the ability of the aquifer layer to drain fluid is low. It can be concluded that the groundwater potential in this area is small or local where it is only sufficient for personal consumption.

\section{Acknowledgment}

The authors would like to thank the students and technical staff of Geophysical Engineering, Faculty of Engineering, Universitas Syiah Kuala for helping us collecting the data in the field. Special thanks are extended to the Ministry of Education and Culture, Indonesia for supporting the scheme of PDUPT 2020 Program.

\section{References}

Abdulrazzaq, Z.T., Al-Ansari, N., Aziz, N.A., Agbasi, O.E., Etuk, S.E., 2020. Estimation of main aquifer parameters using geoelectric measurements to select the suitable wells locations in Bahr Al-Najaf depression, Iraq. Groundw. Sustain. Dev. 11, 100437. https://doi.org/https://doi.org/10.1016/j.gsd.2020.10043 7

Alfadli, M.K., Natasia, N., 2017. Geoelectricity Data Analysis For Identification The Aquifer Configuration In Bandorasawetan , Cilimus , Kuningan , West Java Province 02.

Baeckmann, W. von, Schwenk, W., Prinz, W., Baeckmann, W. von, 1997. Handbook of cathodic corrosion protection theory and practice of electrochemical protection processes.

Barber, A.J., Crow, M.J., Milsom, J.S., 2005. Sumatra: Geology, Resources and Tectonic Evolution. https://doi.org/10.1144/GSL.MEM.2005.031

Bayewu, O.O., Oloruntola, M.O., Mosuro, G.O., Laniyan, T.A., Ariyo, S.O., Fatoba, J.O., 2018. NRIAG Journal of Astronomy and Geophysics Assessment of groundwater prospect and aquifer protective capacity using resistivity method in Olabisi Onabanjo University campus , AgoIwoye , Southwestern Nigeria. NRIAG J. Astron. Geophys. 7, 347-360. https://doi.org/10.1016/j.nrjag.2018.05.002

Bennet, J D, Bridge, D.McC., Cameron, N.R., Djunuddin, A., Ghazali, S.A.,, Jeffery, D.H., Kartawa, W., Keats, W., Rock, N.M.S., Thomson, S.J., Whandoyo, R., 1981. Geologic Map of the Banda Aceh Quadrangle, Sumatra.

Chandra, S., Dewandel, B., Dutta, S., Ahmed, S., 2010. Geophysical model of geological discontinuities in a granitic aquifer: Analyzing small scale variability of electrical resistivity for groundwater occurrences. J. Appl. Geophys. 71, 137-148. https://doi.org/https://doi.org/10.1016/j.jappgeo.2010.0 6.003

Dahlin, T., 2001. The development of DC resistivity imaging techniques. Comput. Geosci. 27, 1019-1029. https://doi.org/https://doi.org/10.1016/S00983004(00)00160-6

Darisma, D., Marwan, 2019. One-dimensional magnetotelluric inversion using levenberg-marquardt and particle swarm optimization algorithm. \{IOP\} Conf. Ser. Earth Environ. Sci. 364, 12035. https://doi.org/10.1088/17551315/364/1/012035

Davis, R.J., DeWiest, S.N., 1966. Hydrogeology. John Wiley \& Sons. https://doi.org/https://doi.org/10.1016/00221694(68)90062-0

deGroot- Hedlin, C., Constable, S., 1990. Occam's inversion to generate smooth, two- dimensional models from magnetotelluric data. GEOPHYSICS 55, 1613-1624. https://doi.org/10.1190/1.1442813

Fetter, C.W., 2001. Applied Hydrogeology. Prentice Hall, New Jersey.

Hasan, M., Shang, Y., Jin, W., Akhter, G., 2020. Estimation of hydraulic parameters in a hard rock aquifer using integrated surface geoelectrical method and pumping test data in southeast Guangdong, China. Geosci. J. https://doi.org/10.1007/s12303-020-0018-7 
Henriet, J.P., 1976. Direct Applications Of The Dar Zarrouk Parameters In Ground Water Surveys*. Geophys. Prospect. 24, 344-353. https://doi.org/doi:10.1111/j.1365-2478.1976.tb00931.x

Krásný, J., 1993. Classification of Transmissivity Magnitude and Variation. Groundwater 31, 230-236. https://doi.org/10.1111/j.1745-6584.1993.tb01815.x

Loke, M.H., Barker, R.D., 1996. Rapid least-squares inversion of apparent resistivity pseudosections by a quasi-Newton method1. Geophys. Prospect. 44, 131-152. https://doi.org/10.1111/j.1365-2478.1996.tb00142.x

Maillet, R., 1947. The Fundamental Equations Of Electrical Prospecting. Geophysics 12, 529-556. https://doi.org/10.1190/1.1437342

Metwaly, M., El-Qady, G., Massoud, U., El-Kenawy, A., Matsushima, J., Al-Arifi, N., 2010. Integrated geoelectrical survey for groundwater and shallow subsurface evaluation: case study at Siliyin spring, ElFayoum, Egypt. Int. J. Earth Sci. 99, 1427-1436. https://doi.org/10.1007/s00531-009-0458-9

Mohamaden, M.I.I., Ehab, D., 2017. NRIAG Journal of Astronomy and Geophysics Application of electrical resistivity for groundwater exploration in Wadi. NRIAG J. Astron. Geophys. 6, 201-209. https://doi.org/10.1016/j.nrjag.2017.01.001

Mohamaden, M.I.I., Hamouda, A.Z., Mansour, S., 2016. Application of electrical resistivity method for groundwater exploration at the Moghra area , Western Desert , Egypt. Egypt. J. Aquat. Res. 42, 261-268. https://doi.org/10.1016/j.ejar.2016.06.002

Muchingami, I., Hlatywayo, D.J., Nel, J.M., Chuma, C., 2012. Electrical resistivity survey for groundwater investigations and shallow subsurface evaluation of the basaltic-greenstone formation of the urban Bulawayo aquifer. Phys. Chem. Earth 50-52, 44-51. https://doi.org/10.1016/j.pce.2012.08.014

Perdomo, S., Kruse, E.E., Ainchil, J.E., 2018. Estimation of hydraulic parameters using electrical resistivity tomography (ERT) and empirical laws in a semiconfined aquifer. Near Surf. Geophys. 16, 627-641. https://doi.org/10.1002/nsg.12020

Sasaki, Y., 1992. RESOLUTION OF RESISTIVITY TOMOGRAPHY INFERRED FROM NUMERICAL SIMULATION1. Geophys. Prospect. 40, 453-463. https://doi.org/10.1111/j.1365-2478.1992.tb00536.x

Soupios, P.M., Kouli, M., Vallianatos, F., Vafidis, A., Stavroulakis, G., 2007. Estimation of aquifer hydraulic parameters from surficial geophysical methods: A case study of Keritis Basin in Chania (Crete - Greece). J. Hydrol. 338, 122-131. https://doi.org/https://doi.org/10.1016/j.jhydrol.2007.02. 028

Suryadi, A., Bagus, D., Putra, E., Kausarian, H., Prayitno, B., 2018. Engineering, Environment, and Technology Groundwater exploration using Vertical Electrical Sounding ( VES ) Method at Toro Jaya, Langgam, Riau 03, 226-230. https://doi.org/10.24273/jgeet.2018.3.4.2226

Syukri, M., Saad, R., 2017. Seulimeum segment characteristic indicated by 2 -D resistivity imaging method. NRIAG J. Astron. Geophys. 6, 210-217. https://doi.org/10.1016/j.nrjag.2017.04.001

Telford, W.M., Geldart, L.P., Sheriff, R.E., 1990. Applied Geophysics, 2nd ed. Cambridge University Press. https://doi.org/10.1017/CBO9781139167932

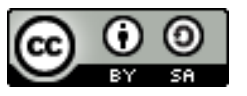

(C) 2020 Journal of Geoscience, Engineering, Environment and Technology. All rights reserved. This is an open access article distributed under the terms of the CC BY-SA License (http://creativecommons.org/licenses/by-sa/4.0/). 